\title{
Mobile characters, mobile texts: homelessness and intertextuality in contemporary texts for young people
}

\begin{abstract}
Since the 1990s, narratives about homelessness for and about young people have proliferated around the world. A cluster of thematic elements shared by many of these narratives of the age of globalization points to the deep anxiety that is being expressed about a social, economic, and cultural system under stress or struggling to find a new formation. More surprisingly, many of the narratives also use canonical cultural texts extensively as intertexts. This article considers three novels from three different national traditions to address the work of intertextuality in narratives about homelessness: Skellig by UK author David Almond, which was published in 1998; Chronicler of the Winds by Swedish author Henning Mankell, which was first published in 1988 in Swedish as Comédia Infantil and published in an English translation in 2006; and Stained Glass by Canadian author Michael Bedard, which was published in 2002. Using Julia Kristeva's definition of intertextuality as the "transposition of one (or several) sign systems into another," I propose that all intertexts can be thought of as metaphoric texts, in the precise sense that they carry one text into another. In the narratives under discussion in this article, the idea of homelessness is in perpetual motion between texts and intertexts, ground and figure, the literal and the symbolic. What the child characters and the readers who take up the position offered to implied readers are asked to do, I argue, is to put on a way of seeing that does not settle, a way of being that strains forward toward the new.
\end{abstract}

Keywords: homelessness, metaphor, young people's narratives, intertextuality, transposition, globalization, Julia Kristeva, street kids, uncanny, home 
Children on the move is the situation at the heart of most children's literature. ${ }^{1}$ As Perry Nodelman and I argue in The Pleasures of Children's Literature, the most common story for young people is a circular journey, in which a central child character leaves home in search of an adventure or is pushed out of an originary home by the behavior of powerful adults, journeys to an unfamiliar place, and, after a series of exciting and/or dangerous experiences, returns home or chooses to claim the unfamiliar space as a new home. ${ }^{2}$ The new millennium, however, has seen an increasing number of narratives for young readers internationally that challenge the terms of the earlier pattern. Since the 1990s, narratives about child subjects on the move have proliferated around the world: these children might be immigrants, refugees, or exiles, if the narrative is working within political valences; vagrants, street kids, runaways, or "throwaways," if the narrative is working within (or against) the genre of domestic realism that continues to dominate the field of young people's texts; or tourists and travelers, if the narrative is working within the terms of fantasy and adventure (including comic misadventure). What distinguishes these recent narratives from the generic pattern is that the central child characters do not move inside or settle at the conclusion of their narratives. Rather, they find happy endings - or, at least, narrative closure - in remaining homeless at the end of their stories.

My most systematic mapping of such narratives has occurred within the Canadian context. Between 1999 and 2008, at least twenty-four novels for young people featuring mobile child subjects were published in Canada. Many of these narratives clearly locate themselves within the context of a social-justice pedagogy and are concerned with both teaching young people the facts of homelessness and promoting thoughtful reflections on the underlying social causes of which homelessness is the symptom; but readers are also invited to understand the young characters in the text more abstractly, as figures that represent possible ways of being in the world. The relevant context for this interest in homelessness, I've argued in several of my articles over the past few years, is globalization, a world system that, according to political theorists Michael Hardt and Antonio Negri, takes "as its very conditions of possibility" "[c]irculation, mobility, diversity, and mixture" (150). ${ }^{3}$ The cluster of thematic elements shared by these narratives points to the deep anxiety that is being expressed about a social, economic, and cultural system under stress or struggling to find a new formation: porous and confused boundaries between inside and 
outside; mental illnesses and addictions; broken relationships with fathers and father figures; the regular intrusion of police and other institutional representatives into the lives and stories of the main characters; an interest in numbers, sometimes money and sometimes random sets of numbers; and a focus on communication systems, often specifically computers and the Internet.

Surprisingly, many of the Canadian narratives also allude to texts of "elite" culture and often use these "elite" texts extensively as intertexts - Mozart's opera The Magic Flute, Einstein's theories of relativity, and Van Gogh's painting Starry Night are just a few examples that come to mind. ${ }^{4}$ In my past work, as I've tried to decipher the ways in which writers for young people translate the vocabularies of globalization into fiction, this item on the list of shared thematic elements has continued to perplex me. Networked communication systems are both the literal vehicle of, and the metaphor for, globalization, but it is not clear how canonical cultural intertexts from earlier periods fit into this framework. Moreover, the Canadian texts are not unique in this regard; rather, this characteristic appears to be common in texts about homeless young people from many places.

In this article, I consider three narratives from three different national traditions, in order to ask the question of the work of intertextuality in narratives about homelessness. The three texts are Chronicler of the Winds by Swedish author Henning Mankell, which was first published in 1988 in Swedish as Comédia Infantil and published in an English translation in 2006; Skellig by British author David Almond, which was published in 1998; and Stained Glass by Canadian author Michael Bedard, which was published in 2002. My project is an exploratory rather than finished one, and the article itself is structured as an account of my attempt to puzzle out the significance of the insistent use of intertexts in this group of texts. At the end of the article, I make the claim that these books set in motion the desire to wander: in retrospect, I can see the wandering line of my argument to be an intellectual response to this invitation.

All three of the texts I've selected for this initial exploration are somewhat eccentric in relation to the thematic cluster of the Canadian texts. In Skellig, there is no broken relationship with father or mother, although there are fears of the death of a sister. In Skellig and Stained Glass, the central child characters are not themselves homeless, although both boys have recently moved into new homes; in both books, as well, the relationship between the protagonist and a homeless character is not only at the center of the 
plot, but also the subject of extensive reflection for the character and narrator. Chronicler of the Winds is not explicitly directed to young readers, but it is the story of a young street child in an African port city and, like the other two books, it thematizes questions of home and not-home. All three of the books are tissues of intertexts and citations. My hope is that, by looking to texts at the margins of the form I've been studying, I will be able to identify the assumptions subtending this practice of intertextuality.

Chronicler of the Winds is a novel about a ten-year-old homeless boy, Nelio, who lives on the streets of an unnamed city in Africa (presumably Maputo, a port city in Mozambique, given the cover description of the author's position as director of a theatre in this city). The narrator of the novel is José Antonio Maria Vaz, a young baker who listens to Nelio tell the story of his short life over nine days, as Nelio lies dying on the roof of the bakery where José works: the narrative tells of Nelio's escape from the bandits who attacked and burned his village and killed many of its inhabitants, all in the name of liberating them; his travels with an albino dwarf through the hills to the sea, the shore of which Nelio follows to the city; his life on the streets of the city with the group of other street kids whom he chooses as his family; and, finally, the events leading to the moment when he is shot on the stage of a theatre that he and his gang have broken into at night. Chronicler of the Winds opens with three epigraphs - from Angelus Silesius, a seventeenthcentury German mystic and poet; from Voltaire; and from the biblical book of Proverbs. Stories and songs remembered by the street boys from their early home lives are woven into the story that José tells.

Skellig is the story of ten-year-old Michael, who has recently moved with his family to a new house in a new area of town, and who finds a vagrant, Skellig, sheltering in the derelict garage in the back garden. Skellig appears to be close to death, and Michael, in trying to figure out how to help him without alerting adults (whom he believes will be either incredulous or exploitative), enlists his new friend from next door, home-schooled and independent-minded Mina. The young people gradually come to see that Skellig is an uncategorizable being, a composite creature - part human, part owl, part angel - who cannot be defined by any "single knowledge system," as Elizabeth Bullen and Elizabeth Parsons put it (127). At the same time as the two young people help to restore Skellig to himself, Michael's baby sister, born with a defective heart, fights for her young life. The novel is peppered with references to 
other texts - the local Chinese takeout menu, Greek myths, science textbooks on evolution, encyclopedia entries about birds, and the poetry of William Blake.

Finally, Stained Glass is the account of a weekend in the life of a young teenager, Charles, who has moved with his mother and siblings into his grandmother's house after the sudden death of his father. The novel begins with Charles escaping into an old church to avoid the piano lessons that he inexplicably no longer wants to take. While he is there, Charles sees the caretaker accidentally break one of the stained-glass windows he is cleaning and comes to the aid of Ambriel, a confused young vagrant who seems to have been struck by the falling glass while sleeping on a bench in the church and who, perhaps for this reason, does not know who she is or how she has come to be in St. Bart's. (A secondary narrative, which focuses on the caretaker's repair of the window, opens another possible explanation for readers - that Ambriel has escaped from the text represented in the stained glass when it broke.) The primary narrative involves the journey of the two young people through the streets of the small Ontario town of Caledon as they try to piece together her identity. The novel is laced together with intertexts: epigraphs from the poetry of Emily Dickinson and T. S. Eliot, interpolations from medieval treatises on glassmaking, a detailed description of the layered transparencies that compose the illustration of the human body in a medical dictionary, and allusions to fairy tales from A Wonder Book of Tales for Boys and Girls, among others.

As I review the lists of texts set into the three narratives that I've taken to be exemplary texts about young people and homelessness, I realize that my initial characterization of the intertexts as "elite" texts may itself have been a stumbling block in my search for an understanding of their significance. Clearly, not all of the important intertexts in this group of narratives are, in fact, iconic texts of high culture: neither the takeout menu in Skellig nor the medical dictionary in Stained Glass, for example, could be described in these terms. What, then, might be a better descriptor for them? The way forward, it seems, might be to take a step sideways and to look again at the critical term intertextuality.

Introduced into French semiotics in the 1960s by Bulgarian psychoanalyst and theorist Julia Kristeva, intertextuality was her representation and development of Mikhail Bakhtin's notions of dialogism and carnival, which she saw as bringing "a dynamic dimension" to structuralist analysis (Desire in Language 65). 
For Bakhtin, she observed, the "literary word" is "an intersection of textual surfaces rather than a point (a fixed meaning)," and "a dialogue among several writings: that of the writer, the addressee (or the character), and the contemporary or earlier cultural context" (65). In a much-quoted passage from Desire in Language in which Kristeva uses the term intertextuality, she employs two more metaphors to convey her sense of the multiplicity and dynamism of the text: "any text is constructed as a mosaic of quotations; any text is the absorption and transformation of another. The notion of intertextuality replaces that of intersubjectivity, and poetic language is read as at least double" (66). Despite her proliferation of explanations, however, intertextual reading in practice often seemed to her to be reduced to the hunt for allusions - "identifying texts that participate in the final text" or "identifying their sources" - as she observed in an 1985 interview with Margaret Waller (281). As a result, she proposed in Revolution in Poetic Language that a better term for the articulation and redistribution of "semiotic polyvalence" that she was describing might be transposition, the "transposition of one (or several) sign systems into another" (59-60). Transposition, in her view, "specifies that the passage from one signifying system to another demands a new articulation of $\ldots$ enunciative and denotative positionality" (60). That is, the movement of one text into another transforms the place(s) from which speech proceeds and the object(s) of that speaking. As Kristeva goes on to observe,

If one grants that every signifying practice is a field of transpositions of various signifying systems (an inter-textuality), one then understands that its "place" of enunciation and its denoted "object" are never single, complete, and identical to themselves, but always plural, shattered, capable of being tabulated. (Revolution, 60)

Critic and theorist Jill Schostak has pointed out that this statement makes it clear that, when "'word' as intersecting textual surfaces emerges, 'word' as Master signifier breaks down" ([10]). According to Schostak, in Kristeva's view of intertextuality, both writers and readers become plural, subjects-in-process: "The intertextual intersection sets in motion ... a sense of the dynamic, the ephemeral and elusive, the invoking-ing, the becoming other, becoming nomad" $([12-13]) .^{5}$

But what does all of this mean in relation to the narratives at hand? What, for example, can we make of the Chinese takeout menu in Skellig, the intertext that seems the least obviously 
meaningful, in light of these definitions and explanations? The name of the restaurant from which Michael's family orders food is never specified in the novel, so it is impossible to know from the text alone whether this particular menu has a pre-text as its source. David Almond has confirmed in an email conversation with me (on 22 March 2013) that he did have a specific text in mind while writing Skellig, the menu of "a very good Chinese takeaway called The Peninsula" in Newcastle, although he invented the specific numbers of the dishes that become important in Michael's story. ${ }^{6}$ But, as Kristeva notes, the hunt for sources is at best a weak form of studying intertextuality. Echoing this observation in the context of mapping the work of ideology in children's literature, John Stephens remarks that "the study of intertextuality is not to be confused with mere source-study," but is, rather, "concerned with how meaning is produced at points of intersection" of various discourses, including those of genre and ideology (117).

If, following Stephens, we consider the discourses in which the Chinese takeout menu is embedded, there is much that we can observe. As a kind of text, the takeout menu is an advertisement and a catalog of goods; it effaces its status as an authored text through its use of impersonal, conventional, functional codes; and it implies a reader seeking information and instructions on purchasing prepared foods (literally an efferent reader, to use Louise Rosenblatt's famous term). The menu assumes the contemporary context of a consumer capitalist society and the historical context of British economic and political adventures in the world: in this sense, the intertext marks what Graham Allen describes as the "text's emergence from the 'social text' but also its continued existence within society and history" (36). Set into the narrative of Michael's search to understand the circumstances of his profoundly changed life - his infant sister's illness, his mother's emotional unavailability to him, his new home, and the now-difficult journey to school - the menu seems to mark the inadequacy of community and nurturance in Michael's social world.

But how could such an intertext be said to shatter the completeness of the text, to return to Kristeva's terms, or to set into motion a sense of the dynamic, to use Schostak's terms? In Desire in Language, in the section immediately preceding her definition of intertextuality, Kristeva remarks that signification "articulates itself" in the space of the text "through a joining of differences" (65). If the takeout menu is read in this light, it can, indeed, be seen to mobilize plural and dynamic objects and places of enunciation. The first explicit mention 
of the menu comes when Michael's father decides to bring in supper for his family on the evening when his wife is to return from hospital: he prepares an order to call in to "the Chinese round the corner" (21). This construction joins that which is adjacent (the local takeaway) with that which is distant (China). The two items on the menu that Skellig requests are given initially only as numbers, $\# 27$ and \#53, arbitrary positions in an ordinal system of classification that puzzle Michael when he hears them. He soon deduces, however, that these arbitrary and abstract symbols also have concrete and specific referents: if one reads them in the context of the takeout menu, they signify spring rolls and pork char sui. Skellig repeatedly apostrophizes the two dishes as the "[f]ood of the gods" (29), although, ironically, he first tasted them after finding leftovers in the trashcan of the previous owner of the house. Michael's father sees their reliance on the takeaway as an irresponsible food choice that will undoubtedly contribute to his problematic body weight but also as a convenience he is unwilling to deny his family in light of their deep emotional distress.

Carried into Almond's text, then, the takeout menu, among other things, joins the adjacent to the distant, the arbitrary to the specific, the abstract to the concrete, human body to divine being, spiritual sustenance to waste material, problem to promise. It multiplies the significations of food. It articulates various positions from which the menu is decoded. These multiple significations and articulations are set in motion and kept in circulation in the signifying field for the reader through the initial unhoming and then the refusal to settle of Michael, the central focalizing character. Michael is unhomed not only because he has moved into a new home from which his mother is absent, but also because the disrupted state of the house (which the family is renovating) makes it difficult for his father to cook and otherwise to keep the household in order. Indeed, Michael's refusal to settle is the subject of much of the narrative and accounts for such actions as his decision not to tell adults about Skellig; his increasingly frequent absences from school, which he justifies to himself as necessary to care for Skellig; and his exploration with his new friend Mina of the abandoned house from which they eventually release Skellig.

In proposing that intertextuality be thought of as transposition, Kristeva suggests that transposition is third in the list of fundamental psychic meaning-making processes, the other two being the processes identified by Sigmund Freud as displacement and condensation, or, in the linguistic terms preferred by Jacques Lacan, the 
figures of metonymy and metaphor (Revolution 59). But, while transposition is a separate process in that it identifies "the passage from one sign system to another," it also "comes about through a combination of displacement [or metonymy] and condensation [or metaphor]" (Revolution, 59). As Kristeva describes transposition, in fact, it seems that all intertexts can be thought of as metaphoric texts, in the precise sense that they transport one text into another text. The literal meaning of the Greek word from which metaphor is derived translates into English as "carry another place" (Tronstad 217). In other words, each of these intertexts as intertext is a metaphor in the sense that, by breaking with its original context and lodging itself in another place, it has become something other than it was and it has transformed the place in which it has lodged itself.

Thought of in this way, it is perhaps not surprising that the writers of these narratives should so often reach for poetic and philosophic intertexts, many of which explicitly articulate the need to see doubly and consider the work of language to be to unsettle. Kristeva highlights this characteristic of poetic language in comparison to prosaic language in her extended discussion of intertextuality in the interview with Waller, where she remarks that "[t]he poetic experience is more openly regressive ... it confronts more directly the moments of loss of meaning" (284). Consider, for example, the epigraph from T. S. Eliot's Four Quartets that opens the first section of Stained Glass, in which Eliot can imagine stillness only as the center of motion:

At the still point of the turning world.

Neither flesh nor fleshless;

Neither from nor towards; at the still point, there the dance is ...

Or, consider the first of the three epigraphs to Chronicler of the Winds, from the seventeenth-century mystic Silesius, in which double vision is understood as the basic condition of the human being:

The human being has two eyes;

one sees only what moves in ephemeral time,

the other

what is eternal and divine.

While some of these philosophic and poetic intertexts are iconic cultural texts, which carry a weight of cultural meaning and are accompanied by a trail of critical commentary, the question of their 
source or status may be less significant than the way in which they instantiate the intertextuality of all human subjects and of all of the objects of human discourse. Indeed, what Kristeva dismisses as the "banal" version of intertextuality, in which it is taken primarily as a "study of sources," might be understood as a readerly attempt to stabilize the text by resituating it within a diachronic tradition rather than opening oneself to the play of "semiotic polyvalence" that the intertext has set in motion (Revolution 60). ${ }^{7}$

At the level of the narratives, unsettling and doubling are the work of the homeless characters in all three of the books. In Almond's novel, there is an unflinching insistence that the reader recognize the abjectness of Skellig's body - "the stench of his breath, the stench of the things the owls had given him to eat" (119) - at the same time as Michael and Mina are "lifted from the floor" to dance with Skellig in the silvery moonlight of the abandoned house in which they have put him for safekeeping (120). To reach toward the new, "to be ready to move forward," and to understand, as Mina speculates, that "this is not how we are meant to be forever," feels to Michael like "calling Skellig out from somewhere deep inside me" (99). Charles, in Bedard's Stained Glass, is acutely conscious of the way in which he is taking on the marks of homelessness as he drifts around town with Ambriel - his clothes are torn, and his lip is bruised from a fall; he is sunburnt and parched with thirst - but he nevertheless feels bereft when Ambriel suddenly disappears without explanation. When, at the end of the narrative, he sees her again (perhaps in a dream) at the window of his upper-story bedroom at night, he experiences "sheer delight" (279). "I could never leave you .... Any more than you could leave me," she tells him, and "they spoke a long time together," Bedard's narrator tells readers, "though whether there were words, [Charles] could not say. It seemed rather that speech sprang from every pore of them" (280). Clearly, then, there is a sense in which Skellig and Ambriel can be read as aspects of Michael and Charles. In this sense, both of these narratives seem to function in part as the "lay analysis" that Kristeva describes as typical of contemporary narratives that incorporate "the poetic experience in an intertextual manner" (Waller 286).

In more general terms, we might say that, in Almond's and Bedard's narratives, the homeless characters Skellig and Ambriel simultaneously unsettle the possibility of the full achievement of home for the central child character and deny the focalizing character any triumphant emancipation from home. The doubleness 
of this condition is captured exactly in the English construction homeless, which in itself both calls up the idea of home and insists on its lack. What is asked both of the child characters and of the readers who take up the position offered to implied readers is to put on a way of seeing that does not settle, that remains restless, a way of being that strains forward toward the new. Chronicler of the Winds literalizes this way of being: at the end of the narrative, we learn that the narrator José has left his good job and his good-enough home to live on the streets with the mission of telling Nelio's story. The world could get along without one baker, he concludes, but "[t]he world could not get along without [Nelio's story]" (226), and he sets out to seek, like a lizard, "a crack in the wall that was wide enough for me," a way of living that would "cost nothing" (229).

The recurrent use of what I initially characterized as "elite" intertexts in the Canadian narratives - and what I would now want to characterize as intertextuality or transpositionality - was one of the first indications to me that these narratives about homelessness were situating themselves within a semantic field larger than that of documentary realism. In other words, to repeat the conclusions I proposed at the beginning of this article, no matter how interested the texts are in issues of social justice or with the underlying causes of homelessness in society, it is also the case that readers are being invited to understand the homeless characters in the text more abstractly, as figures that represent possible ways of being and moving in the world. In one of the early forums at which I reported this conclusion - an interdisciplinary group of social science and humanities scholars at the University of Winnipeg - I was met with considerable resistance: to propose that homelessness could or should be read as a rhetorical figure, as a metaphor, seemed to some of my interlocutors to belittle the plight of a particularly downtrodden segment of society. To appropriate the suffering of such a marginalized group and to exploit it as an explanatory paradigm for the anxieties of the white, middle-class liberal subject at the center of contemporary Canadian society were simply unethical, they said. The response of this group of scholars, many of whom I respect for their activism as much as for their scholarship, sent me back to the critical and theoretical literature on homelessness to reconsider my methods. In Martin Jay's Cultural Semantics: Keywords of Our Time, I found a discussion of exactly this problem. Jay points to the same objection made by my colleagues, quoting the warning of cultural commentator Anthony Vidler about the dangers of trivializing political or social action by 
conflating "reflection on the 'transcendental' or psychological unhomely" with "the intolerable state of real homelessness" (163). The quotation comes in the course of Jay's discussion of the keyword uncanny, the English term that is typically used to translate the German unheimlich, although the German word literally translates into English as "the unhomely." Jay points out that, in the theoretical passages of Freud's concept through the late twentieth century, the term has functioned primarily to unsettle "phantasmatic notions of home" (161) and to deny "the plenitudinous presence of full emancipation" (160), exactly the work that I have already said Skellig and Ambriel do in Almond's and Bedard's narratives. Mankell's novel suggests another possible explanation for the distress that the metaphorical identification of the homeless and the homed seems to cause: perhaps it is not so much that figurative connections between the vagrant and the burger belittle the intolerable condition of real homelessness, as it is that such figurations privilege the condition of homelessness as a model for a responsible, for a good, life.

In the piece from Cultural Semantics that I have mentioned in this article, Jay summarizes the work of what he cleverly calls "the unheimlich manoeuvre" as "tirelessly" "undermin[ing] the hard and fast distinction between the metaphoric and the real, the symbolic and the literal, the animate and inanimate" (163). This, I suggest, is also a good description of the work of homelessness in contemporary texts for and about young people, an idea that is in perpetual motion in these texts between the literal and the metaphoric, the ground and the figure, or what I have called, earlier in this article, the facts and the figures. Philosopher Claire Colebrook, in a discussion of the tactics of metaphor, observes that such thinkers as French philosophers Jacques Derrida and Michel de Certeau "reverse the traditional metaphoric casual chain" in which metaphor "has been seen as a rhetorical effect or secondary movement." For them, she suggests, metaphor can itself only be thought metaphorically, so that it is "[o]nly with the metaphors of figural effect, movement, or passage" that "a prefigural, proper, or ground" can be thought (566). The implication is that the ground or the literal is "the effect of a figuration that has erased itself" (566). Kevin Kohan puts it this way: "Metaphor is not grounded in literal truth, but in fact precedes truth, [and] generates it" (136). In Colebrook's formulation, metaphor always already is a figure of homelessness, in that it is the figure of passage, of movement, of setting in motion. Refusing the figuration of homelessness, then, might be understood 
as an attempt to keep the current systems of meaning in place. On the other hand, writers working and reworking the facts and figures of homelessness might be understood as struggling to articulate a new "prefigural, proper, or ground" (Colebrook 566).

It is just this struggle to articulate a new ground for home that Nelio undertakes in the final chapters of Chronicler of the Winds. In the world as he has found it, he observes, "People no longer build houses, they build hiding places" (182). Home, he thinks, should be something other than a hiding place. He sets out to find the island that his sick friend Alfredo Bomba remembers from a story told to him by his mother and to which he wants to journey before he dies: "If you ever visit that island, afterwards you'll never be afraid of anything for the rest of your life," Alfredo recalls her saying (189). When Nelio's diligent research in the "tattered atlas of the world" that has been "found in a rubbish bin and given to him as a present" by one of his group (181) leads him to recognize that the island does not exist on the "poor maps" of the world that are available to him (193), he begins to build the place from the bits and pieces of the story that Alfredo has told him. "What doesn't exist you have to create yourself," Nelio tells the other boys (198), and they set to work on the empty stage of the theatre at night, assembling the props and rehearsing the play through which Alfredo can complete "the journey that he had dreamed of and prepared for all his life" (213).

The interpolated story of Alfredo's journey is a textbook example of the multiplication of enunciative positions and objects entailed by the simultaneous "adherence to different sign systems" in intertextual discourse (Kristeva, Revolution 60). Set into italics and so marked off from the rest of the narrative, the story is focalized through Alfredo; it is the first extended passage in which readers have been asked to see events through his eyes. It is impossible to determine, however, who is speaking: the novel itself is presented to readers as José's recounting of Nelio's account of his life, but the voice in this passage is not like either of the two voices readers have been accustomed to hearing in the novel. Rather, like the storyteller's voice in a traditional folk narrative, this voice sounds like the amalgamated voice of a tale that has been passed from one teller to another. The objects in the interpolated story exist both on the stage and in the story, demanding at least a double vision: readers know, for example, that Alfredo is the delirious street boy who has been carried into the theatre by his friends but he also appears in the story as the character Old Alfredo Bomba, a wise man who has prepared 
"all his life" for this journey (213). Moreover, the focalizer Alfredo both registers the fact that the dog accompanying him oddly has human hands instead of paws and realizes the truth "that journeys along unknown coasts meant travelling in the company of strange creatures that no one had ever seen before" (213). The effect of the interpolated story is that the reader, too, is asked to travel along unknown coasts with strange companions. Set into the final section of the narrative, the story multiplies, rather than closes, the trajectories of the narrative and unsettles, rather than confirms, the terms of the textual world with which the reader has grown familiar.

Kristeva's description of intertextuality as "the passage of one sign system into another" (Revolution 59) could be read as a gloss on the recent narratives about mobile child subjects in the age of globalization. In these narratives, homeless characters such as Nelio, Skellig, and Ambriel appear to have wandered into the texts from other places and narratives, while homed subjects such as José, Michael, and Charles move toward various states of homelessness. "[I]ntertextuality 'at work' inevitably takes the form of boundarycrossing," according to Patrick O'Donnell and Robert Con Davis, in that "it creates crises, aporiae, ideology wherever it goes" (xiv). Thought of as a metaphorical operation, intertextuality "at work" in these narratives can also be seen as the sign that the thought of going beyond, going beyond the logic of what is, of what is understood to be home and not-home, has been set in motion.

\section{Biographical information: Mavis Reimer is Canada Research Chair in} Young People's Texts and Cultures and professor of English at the University of Winnipeg in Canada. She is editor of the scholarly journal Jeunesse: Young People, Texts, Cultures and serves at present as president of the International Research Society for Children's Literature. She is coauthor, with Perry Nodelman, of The Pleasures of Children's Literature (3rd ed.).

\section{Notes}

${ }^{1}$ This article is based on a keynote lecture presented at the Nordisk forskerkonferanse that took place in Oslo, Norway, in August 2012. The author acknowledges the research assistance of Charlie Peters in preparing both the keynote address and this article.

${ }^{2}$ See the chapter entitled "Children's Literature as Repertoire," in The Pleasures of Children's Literature, pages 184-217.

${ }^{3}$ See my essay, "No Place like Home': The Facts and Figures of Homelessness in Contemporary Texts for Young People," for a detailed argument about the ways in which these texts take up the rhetoric of the theorists of 
globalization. See also my essay, "On Location: The Home and the Street in Recent Films about Street Children."

${ }^{4}$ In, respectively, Martine Leavitt's (2004) Tom Finder, Barbara HaworthAttard's (2003) Theories of Relativity, and Eric Walter's (2007) Sketches.

${ }^{5}$ No page numbers are used in the online document; the numbers in square brackets indicate my count of the pages.

${ }^{6}$ Personal correspondence with the author, 22 March 2013. The Peninsula Takeaway Menu can be viewed at http://www.just-eat.co.uk/restaurantsthepeninsula/menu.

${ }^{7}$ Don Latham's (2008) discussion of David Almond's intertextual practice in three novels demonstrates the pull of the first kind of interpretation, which is also suggested by Latham's emphasis on the "empowerment" of young readers.

\section{Bibliography}

Allen, Graham. Intertextuality. The new critical idiom, 2nd ed. London: Routledge, 2011.

Almond, David. Skellig. New York: Dell Yearling, 1998.

Bedard, Michael. Stained glass. Toronto: Tundra Books, 2002.

Bullen, Elizabeth, and Elizabeth Parsons. "Risk and resilience, knowledge and imagination: the enlightenment of David Almond's Skellig." Children's Literature 35 (2007): 127-144.

Colebrook, Claire. "Certeau and Foucault: tactics and strategic essentialism." The South Atlantic Quarterly 100 (2001): 543-574.

Haworth-Attard, Barbara. Theories of relativity. Toronto: Harper Collins, 2003.

Kohan, Kevin. "Victims of metaphor in The wings of a dove." The Henry James Review 20 (1999): 135-154.

Kristeva, Julia. "Desire in language: a semiotic approach to literature and art". Edited by Leon S. Roudiez. Translated by Thomas Gora, Alice Jardine, and Leon Roudiez. New York: Columbia University Press, 1980.

Kristeva, Julia. Revolution in poetic language. 1974. Translated by Margaret Waller. Introduction by Leon S. Roudiez. New York: Columbia University Press, 1984.

Latham, Don. "Empowering adolescent readers: intertextuality in three novels by David Almond." Children's Literature in Education 39 (2008): 213-226.

Leavitt, Martine. Tom finder. Red Deer, AB: Red Deer Press, 2004.

Mankell, Henning. Chronicler of the winds. 1988. Translated by Tina Nunnally. London: Vintage Books, 2007.

Martin, Jay. Cultural semantics: keywords of our time. Amherst: University of Massachusetts Press, 1998. 
Nodelman, Perry, and Mavis Reimer. The pleasures of children's literature. 3rd ed. Boston: Allyn and Bacon, 2003.

O'Donnell, Patrick, and Robert Con Davis (eds.). "Introduction: intertext and contemporary American fiction." In Intertextuality and contemporary American fiction. Baltimore: Johns Hopkins University Press, 1989, ix-xxii.

Reimer, Mavis. "'No place like home': the facts and figures of homelessness in contemporary texts for young people." Nordic Journal of Childlit Aesthetics 4 (2013). N. pag.

Reimer, Mavis. "On location: the home and the street in recent films about street children." International Research in Cildren's Literature 5 (2012): 1-21.

Rosenblatt, Lousie M. Literature as exploration. 5th ed. New York: Modern Language Association, 1995.

Schostak, Jill. [Ad]dressing methodologies. Tracing the self in significant slips: shadow dancing. 2005. Web. 3 Dec. 2012. http://www.imaginativespaces.net/ thesis/contentsthesis.html

Stephens, John. Language and ideology in children's fiction. London: Longman, 1992.

Tronstad, Ragnhild. "Could the world become a stage? Theatricality and metaphorical structures." Substance 31 (2002): 216-224.

Waller, Margaret. "An interview with Julia Kristeva." 1985. Translated by Richard Macksey. In Intertextuality and contemporary American fiction. Edited by O'Donnell, Patrick, and Robert Con Davis. Baltimore: Johns Hopkins University Press, 1989, 280-293.

Walters, Eric. Sketches. Toronto, ON: Penguin-Puffin, 2007. 